\title{
Avaliação da Atividade Antimicrobiana do Óleo Essencial de Rosmarinus Officinalis Frente À Alicyclobacillus Acidoterrestris.
}

Angela Aparecida Silva (I), Idinea Fernandes Santos (I), Márcia Maria Anjos (I), Suelen Pereira Ruiz (I), Isabela Carolini Pascoli (I), Daniela Biral Prado (I), Jane Martha Graton Mikcha (I), Miguel Machinski Júnior (I), Benício Alves Abreu Filho (I)

(I) UEM - Universidade Estadual de Maringá (Avenida Colombo, 5790 - Jardim Universitário, Maringá - PR, 87020-900)

\section{Resumo}

A procura por alimentos e por uma vida mais saudável vem crescendo consideravelmente. O suco de laranja concentrado é um produto com grande importância comercial e nutricional. Alicyclobacillus acidoterrestris é um bacilo acidotermorresitente e formador de esporos, fato que contribui para seu crescimento e desenvolvimento em alimentos acidificados, mesmo que estes passem por processo de pasteurização. A presença de A. acidoterrestris no suco de laranja é um indicativo de que o produto está fora do padrão de qualidade, ou seja, existe a presença de micro-organismos. Por isto, há muitas pesquisas com uso de os óleos essenciais e sua aplicação em vários ramos, inclusive na área alimentar, pois possuem boa aceitabilidade pelo consumidor, além de serem classificados pela FDA (Food and Drug Administration) como GRAS (Generally Recognized as Safe). Este trabalho mostra a ação do óleo essencial de Rosmarinus officinalis frente à A. acidoterrestris (CBMAI $0244^{\mathrm{T}}$ ) através da técnica da microdiluição seriada em placa de 96 poços. Através deste ensaio foi possível avaliar a Concentração Inibitória Mínima (CIM) e a Concentração Bactericida Mínima (CBM). Em nossos ensaios, foi utilizado o meio de cultura BAT (Bacillus acidoterrestris), com pH 4,0 ajustado com $\mathrm{HCl} / \mathrm{NaOH} 1 \mathrm{~mol} / \mathrm{L}$. As concentrações do óleo essencial avaliado variou de 
2.000 à $25.000 \mu \mathrm{g} / \mathrm{mL}$. Para a avaliação da CIM foram realizadas microdiluições seriadas contendo um volume total em cada poço da microplaca de $100 \mu \mathrm{L}$ da solução (meio de cultura e óleo essencial), em seguida adicionados $5 \mu \mathrm{L}$ do inóculo bacteriano na concentração de $10^{4}$ $\mathrm{UFC} / \mathrm{mL}$ e incubado por 24 horas a $45^{\circ} \mathrm{C}$. A CIM foi considerada como a menor concentração capaz de inibir o crescimento de A. acidoterrestris no poço da microplaca. Para avaliação da CBM, foram realizados microcultivos de $10 \mu \mathrm{L}$ em placa ágar BAT dos poços que não houveram crescimento bacteriano observado visivelmente. A CBM foi considerada como o não crescimento de colônias após plaqueamento seguido de incubação por 24 horas a $45^{\circ} \mathrm{C}$. A CIM e a CBM obtidas foram de $2.000 \mathrm{e}$ $25.000 \mu \mathrm{g} / \mathrm{mL}$, respectivamente. Foi observado uma redução microbiana de 3,43 Log UFC/mL no tratamento empregando uma concentração de 2.000 $\mu \mathrm{g} / \mathrm{mL}$ do óleo essencial. Os resultados sugerem que o óleo essencial de R. officinalis pode ser utilizado como agente antimicrobiano frente à A. acidoterrestris, apesar de não apresentar bons resultados quando a concentração empregada, no entanto são necessárias mais pesquisas quanto a sua ação combinada com outros agentes antibacterianos naturais, sua citotoxicidade e sua aplicação em sucos concentrados de laranja.

Palavras-Chave: Alicyclobacillus acidoterrestris, agente antibacteriano, Rosmarinus officinalis, suco de laranja

Agência de Fomento: PPG/UEM/CAPES. 